\title{
DOES THE TAX RELIEF FOR HOMEOWNERSHIP HAVE EFFECT ON HOUSEHOLD MORTGAGE LEVERAGE?
}

\author{
Barbora Slintáková, Stanislav Klazar
}

\section{Introduction}

Tax systems of developed countries contain provisions that give a preferred status to housing and homeownership. A significant relief is provided especially by the combination of non-taxation of imputed rental income and mortgage interest payment deductibility. Real user costs of owner-occupied housing are reduced (see Poterba \& Sinai, 2008) and thus a bias in favour of the homeownership is created when households are encouraged to buy rather than to rent their dwellings. Although there is a property tax, that is levied to tax the imputed rent, the relief for the mortgage interest payment can be so generous that it mitigates the effect of the property tax (Crowe, Dell'Ariccia, Igan, \& Rabanal, 2011). The fact is that the property tax in many countries is not high enough to be a perfect substitute for the imputed rent taxation (Hemmelgarn \& Nicodéme, 2010). Furthermore, homeownership is more attractive when capital gains are not taxed in a neutral manner. And profits from home sales are not usually taxed. The housing-related tax allowances are one of main tax expenditure items in EU countries (see European Communities [EC], 2013).

The pro-homeownership tax policy is justified by market failures and a desire to enhance housing opportunities available to citizens (Andrews, Caldera Sánchez, \& Johansson, 2011). However it seems that for the time being economists rather conclude that the tax advantages provided to homeowners are not very efficient at achieving given objectives. A general goal in practice is to boost the homeownership or to increase housing demand and consumption. Cecchetti, Mohanty, and Zampolli (2011) claim that the generous tax relief for mortgage interest payment could have played a role in expanding the homeownership in some countries. However according to Andrews, Caldera Sánchez, and Johansson
(2011) there is no clear cross-country relationship between the extent of the mortgage interest deductibility and the homeownership rates. Nevertheless they admit that households' preference for the homeownership can be influenced also by tax policy. Bourassa and Grigsby (2000) or Glaeser and Shapiro (2002), based on empirical evidence on U.S. situation, concluded that impact of the mortgage interest deductibility on the homeownership rate was minimal. And Crowe et al. (2011) even assert that the homeownership rates are negatively related to the extent of the advantageous tax treatment of homeownership.

An argument in favour of a higher rate of the homeownership is existence of positive externalities, e. g. enjoyment of neighbours and passersby generating through home maintenance and gardening, better outcomes for children, and long-term prospects of a community (Bourassa \& Grigsby, 2000 or Glaeser \& Shapiro, 2002). Glaeser and Shapiro (2002) think that evidence on externalities is weak but suggestive. But Hilber and Turner (2013) believe that the homeownership generate few or no positive externalities. Moreover, there could be negative externalities related to housing consumption, e. g. leaving small city apartments for larger places on the fringe of a city, increasing segregation by income or envy incited by fancy homes (Glaeser \& Shapiro, 2002). A lower labour mobility and higher unemployment among owneroccupants in comparison with the mobility and unemployment of renters can be harmful effect of the homeownership as well (Andrews, Caldera Sánchez, \& Johansson, 2011). Finally, the homeowners could utilize their political power to cut off new house construction in order to raise their house prices (Glaeser \& Shapiro, 2002). As O'Sullivan and Gibb (2012) summed it up, the homeownership does not 
generate economic benefits for the macroeconomy or specific households which would justify a general programme of tax concessions to homeowners.

As an argument supporting the owneroccupation we could present that accumulated housing wealth could serve as means of private insurance (Ansell, 2013) or that home equity could provide an additional source of retirement income beyond pensions, i.e. reverse mortgages (Toussaint, 2013). However we are not familiar so far with any evidence that the owner-occupation serves well as an instrument of pension security. On the other hand, what is already a subject of examination is correlation between the mortgage interest deductibility and growth of house prices or increased house prices volatility. Organisation for Economic Cooperation and Development [OECD] (2009) or Andrews, Caldera Sánchez, and Johansson (2011) offer some evidence of a positive correlation between the tax relief on mortgage interest and variability in house prices. Keen, Klemm, and Perry (2010), André (2010), Sutherland, Hoeller, Merola and Ziemann (2012) or further authors point out that the tax subsidy is likely, depending on a price elasticity of housing supply, to be capitalised into house prices. In addition the tax incentive for debtfinancing over other sources of financing of own dwellings could result in overinvestment in housing and misallocation of capital stock with negative effects on a long-term economic growth (see e.g. Saarimaa, 2009; André, 2010; Hemmelgarn \& Nicodéme, 2010; Ventry, 2010). Finally, there is agreement among authors that the housing tax relief is regressive, i.e. it favours rich households. Higher-income households benefit from the advantageous tax treatment of housing, namely from the mortgage interest deductibility, more than lower-income households because they have higher rates of the homeownership, they buy more expensive houses, and their marginal tax rates are higher (see Bourassa \& Grigsby, 2000; André, 2010; Keen, Klemm, \& Perry, 2010; Matsaganis, 2014; Ventry, 2010; Andrews, Caldera Sánchez, \& Johansson, 2011).

There is another important reason why the housing taxation, especially the mortgage interest deductibility, attract attention of economists. It is because it might support debt creation. Jorda, Schularick, and Taylor (2014) found that household leverage ratios have increased substantially in many countries over the 20th century: about two thirds of bank lending today consists of the loans to the household sector for the purchase of real estate, according to European Central Bank [ECB] (2014) the majority of the European household borrowing is comprised by loans for house purchase. Furthermore they showed that contemporary business cycles are increasingly shaped by the dynamics of the mortgage credit and that the mortgage credit became a specific source of financial instability in advanced economies after the Second World War. And Jorda, Schularick, and Taylor (2015) demonstrated that the credit-financed housing price bubbles are more dangerous for financial sector and real economy than the unleveraged bubbles. How indebtedness can affect macroeconomic performance and households, see Sutherland et al. (2012) or McGowan (2013). The household indebtedness impact on economic growth have been analysed by Izák (2012).

A question raises whether the housing taxation, and the presupposed debt bias embedded in it, does affect the household indebtedness, and whether the negative consequences of high levels of debt could be, partly, extra cost of the taxation favouring housing. Hemmelgarn and Nicodéme (2010), Keen, Klemm, and Perry (2010), Bernardi (2011), Cecchetti, Mohanty, and Zampolli (2011), Hemmelgarn, Nicodéme, and Zangari (2011), Sutherland et al. (2012) or Garnier et al. (2013) suggest that the tax treatment of owneroccupied housing may have played a role. Households have been probably encouraged by the mortgage interest relief to prefer borrowing. As a result the household debt may be higher than it would be otherwise. Wolswijk's (2005) simple graphical analysis shows that the lower the financing costs, decreased by the tax subsidy, the higher the debt-GDP ratio. Keen, Klemm, and Perry (2010) affirm that countries offering more favourable tax treatment for the homeownership have higher ratios of mortgage debt. On the other hand Crowe et al. (2011) do not see a significant relation between the tax treatment of housing and the ratio of the mortgage debt to GDP. It is necessary to be careful, e.g. Ellis (2006, p. 11) warns that it is not easy to prove the correlation between the tax advantages for the homeownership and the household debt since "the tax regime interacts 
with other aspects of the housing-finance system in sometimes complex ways". OECD (2009) points out that home-equity loans and real house prices have risen in many countries despite the fact that tax incentives varied considerably. It suggests that other factors affect these phenomenons. However OECD (2009) also admits that the high tax relief on mortgage interest correlates with the high variability in house prices which can lead to serious household credit problems.

Deeper insight into the relationship between the tax incentive and household debt can be provided by studies concerning individual countries. Dunsky and Follain (2000) or Munroe (2014) analysed the United States data and found out that the demand for home mortgage debt responded to the mortgage interest deduction. Hendershott, Pryce, and White (2002) revealed that the homeowner leverage in the United Kingdom was sensitive to the deductibility of mortgage interest. Alan and LethPetersen (2006) examined the 1987 tax reform in Denmark which made the holding of debt less attractive. Rouwendal (2007) identified the tax incentive for financing the homeownership with a mortgage as important driving force behind the increase in frequency of mortgage use in the Netherlands. According to Sommervoll (2007) Norwegian households reduced their debt as a response to less generous interest deductions after the tax reform. Finally, Saarimaa's (2009) results from the study of the impact of the tax reform in Finland indicate that high income households with high marginal tax rates responded to the tax incentive reduction by clearly decreasing their mortgage borrowing. On the other hand Jappelli and Pistaferri (2004) found no evidence that the tax treatment shaped the demand for mortgage debt in Italy. It is possible to sum up that tax reforms, that reduced value of the mortgage interest relief (which is affected also by a marginal tax rate) and thus weakened the incentive to borrow in order to own home, mostly led to lower household leverage. This could prove the role of the tax incentive favouring the debtfinanced homeownership (see the European Commission taxation papers about tax reforms published in 2011-2014). After all, the European Commission recommends to the EU Member States to reduce the debt bias in their housing taxation and subsequently maps changes in taxation rules in the member countries, see e.g.
(EC, 2014). Garnier et al. (2013) confirm that major changes in the housing taxation in many countries concerned the debt bias and focused on limiting the deductibility of mortgage interest. Nevertheless Sommervoll (2007) points out that effects of tax reforms on housing markets can be offset by other factors in the economy.

Of course, the housing taxation is not the only factor influencing the household demand for mortgage. Interest rates, financing conditions (i.e. financial deregulation and innovation on financial market), income and demography have been identified in both theoretical and empirical studies as important determinants of the household indebtedness. In addition, factors characterising housing market, especially house prices, should be taken into consideration, too - see e.g. Debelle (2004), Jacobsen and Naug (2004), Girouard, Kennedy, and André (2006), Dynan and Kohn (2007), ECB (2009), André (2010) or Bokhari, Torous, and Wheaton (2013).

Aim of our research was to explore whether there is the relation between the income tax incentive for homeowners, i.e. the mortgage interest deductibility and exempted imputed rent income, and the household indebtedness. To the contrary to studies mentioned above, which analysed microdata, we conducted a cross-country study like Wolswijk (2005) who analysed impact of the housing taxation on the mortgage debt growth in EU countries on assumption that the taxation may have a potentially large role in affecting the household leverage. The remainder of the paper is divided into three sections and a conclusion. In the next section we focus on the construction of our key explanatory variable representing the tax treatment of the owner-occupied housing which is supposed to be debt encouraging. Then we describe briefly the other explanatory variables we worked with. The econometric methods we used are discussed in section 2 and section 3 reports results.

\section{Variables Used in the Household Mortgage Leverage Regression Model}

We followed Wolswijk's (2005) work in our research. Wolswijk applied a multiple (panel) regression analysis in order to measure the effect of the fiscal instruments on the mortgage debt growth in the EU countries. We also employed the regression analysis where 
the dependent variable was the household mortgage leverage. The mortgage leverage was measured by the ratio of total outstanding residential loans (on lender's books at the end of the year, in EUR million) to household gross disposable income (in EUR million). The data on both loans and income were provided by the HYPOSTAT 2014 published by the European Mortgage Federation - European Covered Bond Council (EMF-ECBC) - see the webpage http://www.hypo.org/Content/default. asp?PagelD $=524$. The effect of the income tax incentive for homeowners was measured by a special variable - see section 1.1. Considering literature and data availability we proposed a number of the other variables which might explain the household debt - see section 1.2.

\subsection{Construction of the Homeowner Tax Relief Variable}

Wolswijk (2005) constructed the fiscal instruments variable as the after-tax capital costs which captured the deductibility of mortgage interest payment. The capital costs were derived from a nominal mortgage interest rate and amount of mortgage. Then they were adjusted by the relevant tax rate which reflected whether the mortgage interest was deductible from the income tax and whether it was deductible fully or with a limit. The costs were expressed as the percentage of a house price. Since we assumed that individuals consider the mortgage interest and the relief provided by the income tax law rather separately when they make decision on borrowing we decided to include two explanatory variables into our regression model. We used the variable representing the impact of the income tax treatment of housing on the homeowner capital costs besides the mortgage interest payment as another variable.

Our key explanatory variable (the homeowner tax relief) was defined as the ratio of the pre-tax capital costs $\left(\mathrm{CC}_{0}\right)$ to the after-tax capital costs $\left(\mathrm{CC}_{1}\right)$ :

$$
\frac{C C_{0}}{C C_{1}}=\frac{r M}{(r M)-T W}
$$

where $r$ is nominal mortgage interest rate; $M$ is mortgage value; $T W$ is tax wedge.

If the ratio is higher than 1 , housing and homeowners are subsidised by the income tax system. The ratio smaller than 1 means taxation of housing, i.e. imputed rent is taxed since it exceeds the mortgage interest payment. The difference between the pre-tax capital costs and the after-tax capital costs is called the tax wedge and it is used as an indicator of the extent of the tax relief on debt financing of the owner-occupied housing (see e.g. Andrews, 2010). The tax wedge has been calculated also by van den Noord (2003) when he estimated the real financing costs of housing.

To estimate the capital costs before and after taxation and the tax wedge it is necessary to model a taxpayer who might represent the population taking out mortgages. There were two inspirations available to be used. First, we followed Keen, Klemm, and Perry (2010), who used the International Monetary Fund methodology, see Hemmelgarn, Nicodéme and Zangari (2011) or International Monetary Fund (2009), respectively, in order to calculate effective tax rates on the owner-occupied housing for the purpose of international comparison. We made the following assumptions about our model taxpayer: he is an unmarried person with no child in the top income tax bracket who purchased his primary dwelling for a price financed $80 \%$ with a mortgage at a certain interest rate. The assumption about the top income taxpayer was supported by Girouard, Kennedy, and André (2006) according to whom the most indebted households are those with the highest incomes. The top income was defined as double the average wage which is the threshold of the top income tax bracket in the most EU-15 countries. The average wages data were drawn from the OECD Taxing Wages publications. The price of dwelling was estimated as 5-multiple of the top income. The mortgage interest rate was approximated by the annual average of representative interest rates on new residential loans provided by the HYPOSTAT 2014. Moreover, we used the nominal rate like Wolswijk (2005) who argued that it is more relevant for individual's decision-making on the mortgage. Second, since van den Noord (2003) calculated his tax wedge for a single earner couple with two children and Wolswijk (2005) estimated the relevant tax rate for an average family, we created an alternative model taxpayer. We modified the model taxpayer's family status: he is married with two children. We provide results of regression analysis for both single and family taxpayers in the section 3 . 
Like Wolswijk (2005) we wanted to include the former $15 \mathrm{EU}$ member states into our analysis but due to a lack of data our country sample does not contain Greece. We covered the period from 2004 to 2013, i.e. we started when Wolswijk ended. To calculate the aftertax capital costs we had to estimate the tax wedge for every country and each year using effective income tax law provisions. We took into account the mortgage interest deductibility as well as taxation of imputed rent just as van den Noord (2003). Furthermore we explicitly distinguished different tax elements used in income tax codes to favour the owner-occupied housing and dealt with limits on the deductible amount more exactly than Wolswijk (2005).

There were different forms of the tax relief in the EU countries in the given period. Austria, Belgium, Denmark, Luxembourg and the Netherlands applied a deduction from income or a tax base. When the deduction is used the amount, which a taxpayer could save, depends not only on the mortgage interest payment but also on a marginal tax rate (the marginal tax rates were gained from the OECD Taxing Wages publications). Moreover, Belgium, Luxembourg and the Netherlands taxed the imputed rent-then the interest is deductible first against this income. The imputed rent was set either as a fraction of the house price (i.e. for the Netherlands, according to the European Commission taxation papers) or as a percentage of household income (i.e. for Belgium and Luxembourg, according to Eurostat (2013)). A credit lowering a tax liability was applied in Finland, France, Ireland, Italy, Portugal, Spain and Sweden. The tax wedge in this case is easier to estimate because it is equal to the interest. There was no tax relief in Germany and the United Kingdom in the period 2004-2013.

In fact we applied complicated formulas for the tax wedge estimations because there were various limits on the amounts of the deductions or credits. The amounts were usually derived from the mortgage interest payment as a certain percentage and they were mostly capped with a ceiling which somewhere depended on taxpayer's characteristics, e.g. income. Especially, the presence of wife and children increased the ceiling on the credit in Finland, France and Ireland.

The tax wedge should be equal to the sum of annual amounts saved during the period of repaying a mortgage. However since our model taxpayers in all the countries were assumed to repay a mortgage for the same time we could simplify the calculation. The savings on the tax liability were estimated as the amount saved in the first year of the repayment period. Moreover we assumed that the tax treatment of the mortgage interest and imputed rent would be stable over the whole repayment period. In fact, the tax treatment of the owner-occupied housing significantly changed in Belgium, France, Ireland, Portugal or Spain during the period 2004-2013.

Precision of our tax wedges estimates was influenced by quality of available data. We had to rely on information about taxation provided by secondary sources. We compiled the information from the Taxes in Europe database (see the webpage http://ec.europa. eu/taxation_customs/taxation/gen_info/info_ docs/tax_inventory/index_en.htm), the OECD Taxing Wages publications and the European Commission taxation papers published in 2011-2014. Quality of the data differed across countries: some countries did not provide so much details and sometimes different sources did not provide the same data about the same countries.

Neither van den Nord (2003) nor Wolswijk (2005) included the property tax of the homeowner into their calculations of the tax wedge or the after-tax capital costs, respectively. We also ignored this tax on the assumption that there is no difference in the user costs between own and rented housing since the property tax burden is assumed to be fully borne by the individual using the dwelling (i.e. an owner or a tenant). Furthermore, Wolswijk (2005) used a modified fiscal instruments variable, which included taxation of expected capital gains from the house sale, in another specification of his regression model but with no satisfactory results. We ignored the capital gain taxation (the capital gain is usually tax-exempt) as well as transaction taxes on assumption that the model taxpayers do not consider selling their dwelling in future. After all the mortgage interest deductibility combined with the non-taxation of imputed rent are the provisions which are assumed to tilt households to borrowing the most.

\subsection{The Other Explanatory Variables}

Drawing from literature and checking availability of statistical data we identified the following 
variables which might impact on the household indebtedness and which would be suitable for the regression analysis. On assumption that wealthier households are able to borrow more money in order to buy houses we used the GDP and financial worth per capita variables representing wealth. Financial worth per capita was defined as the household financial net worth per capita to annual household income per capita ratio. Supposing that the unemployed people have limited opportunities to borrow the unemployment (rate) variable was added, too.

Mortgage interest payment as a portion of household income constituted the variable representing costs of borrowing in our analysis. The interest payment was derived from the annual average of representative interest rates on new residential loans.

Further underlying driver of the housing debt are house prices. We supposed that the prices could impact on the mortgage demand both negatively and positively. If the prices increase households have to take out larger mortgages. On the other hand increased prices can reduce demand on the housing market and thus a lower amount of mortgage is necessary to acquire dwellings. The house prices development was approximated by the nominal house prices index from the HYPOSTAT 2014 which reflects the changes in house prices observed over the given period. In addition to this "price" variable we included the indicator of the difference between the HYPOSTAT house prices index and the harmonised index of actual rents from the EUROSTAT statistics, hereafter the home-rent wedge variable. The effect of the home-rent wedge on the mortgage leverage was supposed to be negative, i. e. if the own housing price increases in relation to the rental housing price the amount of mortgage debt taken up is supposed to decrease because households prefer the rental housing.

To capture the influence of population structure which might determine the demand for housing we worked with both the young and old dependency ratios. Since seniors have already secured their housing the level of the household mortgage leverage should decrease with a higher portion of older people in population. On the other hand we assumed a positive effect of the young dependency ratio because young people should have a higher need to secure their shelter. Moreover their financial situation presumably allows them to borrow.
Finally, since there were changes in measuring the data necessary for our dependent variable in different years for different countries we used a dummy variable to control for the time series breaks.

Data for the independent variables were obtained from various sources, i.e. from the HYPOSTAT 2014, the OECD statistics, EUROSTAT statistics and the ILO statistics.

Stationarity of data is requested for a proper calculation of $p$-values in regression models of panel data. We used the Levin-Lin-Chu test (LLC), assuming that there was a common unit root process identical across cross-sections, as well as Dickey-Fuller test (ADF-GLS), allowing for individual unit root processes to vary across cross-sections, in order to uncover the presence of unit roots in time series of data of the variables described above for all the countries in our sample. The test designed by Levin, Lin, and Chu (2002) was applied with the constant including 0 lags. The ADF test was done using the GLS procedure suggested by Elliott, Rothenberg, and Stock (1996) with a greater power than the standard DickeyFuller approach. Moreover, the overall test with null hypothesis, that the series in question had a unit root for all the panel units, was calculated using the method of Im, Pesaran, and Shin (2003). Results of the inverse chi-square, inverse normal and logit tests were aggregated using the Choi meta-test (see Choi, 2001; Cottrell \& Lucchetti, 2016) - final results are shown in the last column of Tab. 1. The same null hypothesis $(\mathrm{HO})$ and alternative hypothesis (H1) were formulated for both tests: $\mathrm{HO}$ was that all of the individual time series exhibit a unit root, and $\mathrm{H} 1$ was that none of the series has a unit root. Furthermore if the p-value was low the null hypothesis was rejected which meant that a time series was stationary. Results of the stationarity tests are in Tab. 1.

The $p$-values showed that the financial worth per capita and nominal house prices index series were non-stationary. The data for the financial worth per capita exhibited the unit roots and the stationarity of these data was obtained by first differences. The problem with nonstationarity of the nominal house prices index series was solved by using data on (annual and relative) changes in this index which were also available in the HYPOSTAT 2014. The change in nominal house prices indices series was already stationary and a new variable, labelled 


\begin{tabular}{l|r|r|r|c}
\multirow{2}{*}{\multicolumn{1}{c|}{ variable }} & \multicolumn{3}{c|}{ LLC } & ADF-GLS \\
\cline { 2 - 5 } & coefficient & t-ratio & z-score [p-value] & Meta-tests p-value \\
\hline household mortgage leverage & -0.303110 & -8.524 & $-6.40937[0.0000]$ & $<0.00$ \\
\hline single homeowner tax relief & -0.607120 & -6.050 & $-2.98838[0.0014]$ & NA \\
\hline family homeowner tax relief & -1.012400 & -10.698 & $-6.9322[0.0000]$ & NA \\
\hline GDP per capita & -0.223060 & -3.771 & $-1.18036[0.1189]$ & $<0.00$ \\
\hline financial worth per capita & -0.021903 & -0.567 & $1.58079[0.9430]$ & 0.735 \\
\hline unemployment & -0.606710 & -9.791 & $-5.65002[0.0000]$ & $<0.00$ \\
\hline mortgage interest payment & -0.231590 & -4.070 & $-1.48657[0.0686]$ & $<0.01$ \\
\hline nominal house prices index & -0.092375 & -2.230 & $0.24923[0.5984]$ & $<0.00$ \\
\hline home-rent wedge & -0.679620 & -8.305 & $-5.3787[0.0000]$ & $<0.00$ \\
\hline young dependency ratio & -0.115020 & -8.512 & $-7.70736[0.0000]$ & $<0.00$ \\
\hline old dependency ratio & -0.116960 & -7.551 & $-6.9874[0.0000]$ & $<0.00$ \\
\hline break-point dummy & -0.154430 & -4.144 & $-2.74214[0.0031]$ & $<0.00$ \\
\hline \multicolumn{1}{c|}{ adjusted series } & & & & \\
\hline financial worth per capita (1st-dif.) & -0.661910 & -8.286 & $-4.09091[0.0000]$ & $<0.00$ \\
\hline house prices (change in \%) & -0.495910 & -7.848 & $-5.21249[0.0000]$ & $<0.00$ \\
\hline
\end{tabular}

Descriptive statistics for non-binary variables, observations of $14 \mathrm{EU}$ countries, 2004-2013

\begin{tabular}{l|c|c|c|c|c}
\multicolumn{1}{c|}{ Variable } & Mean & Median & Minimum & Maximum & Std. Dev. \\
\hline household mortgage leverage & 0.990606 & 0.886642 & 0.190009 & 2.26104 & 0.519354 \\
\hline single homeowner tax relief & 1.1738 & 1.1269 & 0.98624 & 2.6178 & 0.23242 \\
\hline family homeowner tax relief & 1.2650 & 1.1401 & 0.98624 & 2.6178 & 0.34274 \\
\hline GDP per capita & 35,193 & 33,462 & 14,534 & 87,231 & 13,302 \\
\hline financial worth per capita (1st-dif.) & 1.1167 & 1.0687 & 0.38264 & 2.2013 & 0.40244 \\
\hline unemployment (\%) & 7.81508 & 7.53600 & 2.75100 & 26.0920 & 3.79661 \\
\hline mortgage interest payment & 0.30541 & 0.30469 & 0.11224 & 0.84372 & 0.10831 \\
\hline house prices (change in \%) & 2.5528 & 2.5337 & -18.776 & 30.769 & 6.6330 \\
\hline home-rent wedge & -0.26071 & 0.0000 & -18.700 & 20.000 & 3.3553 \\
\hline young dependency ratio (\%) & 22.685 & 23.123 & 18.138 & 28.236 & 2.3741 \\
\hline old dependency ratio (\%) & 4.4620 & 4.5180 & 2.6265 & 6.1160 & 0.79377 \\
\hline
\end{tabular}

"house prices", was set up. See the p-values for the adjusted series in the bottom of the Tab. 1. Values of the LLC test for the GDP per capita variable were ambiguous, nevertheless we decided to consider the series as stationary. All the other series were stationary.

Tab. 2 presents descriptive statistics for all the variables used in a regression analysis, 
i.e. the dependent variable as well as the independent variables.

\section{Discussion of Econometric Methods}

Our analysis was based on panels which can be described as balanced. There was an observation for every year (2004-2013, i.e. 10 years) and for every unit (i.e. 14 countries).

In our pilot work (see Slintáková \& Klazar, 2015a or Slintáková \& Klazar, 2015b) we used the pooled OLS method because of its two advantages. First, we gained in efficiency because it was not necessary to allow for non-existent within-groups autocorrelation. Second, we took advantage of the finite-sample properties instead of relying on the asymptotic properties of random effects (see Dougherty, 2007). In case the unobserved effect is weak, i. e. there are no relevant unobserved characteristics, the pooled regression is the best method to describe a relationship between an explained variable and explanatory variables. We believed that we identified such explanatory variables on the basis of literature study and the data availability examination that we could suppose that the unobserved component would not influence our analysis significantly. However we could not be sure that there were any differences among the countries in our sample. That is why we decided to test suitability of the panel data analysis (see Dougherty, 2007 or Gujarati, 1995). The test for differing group intercept, implemented in the gretl software, was performed with the null hypothesis that groups (countries) have a common intercept. The test resulted with the following test statistic: Welch $F(13,48.1)$ $=139.847$ for the single taxpayer model and 288.331 for the family taxpayer model, both with $\mathrm{p}$-value near zero. The null hypothesis was rejected and we concluded that the panel data analysis was more suitable tool than the pooled OLS method. The panel data method would enable to control for the different level of the relationship between the explained and explanatory variables due to different country characteristics.

There are two basic panel data techniques: fixed effects and random effects. We followed the economic fundamentals (a less formal hint) as well as more formal (technical) econometric tests in order to decide which technique should be preferred. The less formal decision was based on the recommendation of Dougherty (2007) who, in case that an observation cannot be described as being a random sample from a given population, recommends using the fixed effects. We supposed that our selected countries sample could not be a random sample. We believed that economic nature of our data was not compatible with the presence of random effects. The more formal tests of BreuschPagan and Hausman were partly in conflict. The Breusch-Pagan test (with the null hypothesis that the variance of the unit-specific error is zero versus the alternative hypothesis of existence of random effects) delivered asymptotic test statistic: Chi-square $(1)=426.747$ for the single taxpayer and 496.52 for the family taxpayer with both $p$-value near zero. The non-random effects hypothesis was rejected at the $5 \%$ level. However the Hausman test suggested that the random effects estimators were inconsistent and thus the fixed effects should be used instead. The Hausman test results are shown below the Tab. 3. To sum up, econometric tests and the nature of the analysed data proved that the fixed effects would be more suitable method to analyse the relationship between the explained and explanatory variables in our case.

We report results from both the fixed effects and random effects models in the Tab. 3 in the section 3. Comparison showed that the coefficient values from the fixed effects models were not, in general, significantly different than the coefficient values from the random effects models. Therefore the fixed effects models results can be considered being robust.

Furthermore, since the explanatory variables effects might differ not only across countries but also over time the period fixed effects were tested by Wald test for joint significance of time dummies ( $\mathrm{HO}$ said that there were not significant period effects). On the basis of the test results (see notes below the Tab. 3) we included time dummies in our regression models.

According to Dougherty (2007) a regression model can be built either from specific to general or from general to specific. On the basis of his summary of pros and cons it seemed that the from specific to general approach would be more suitable for our analysis. We devoted a lot of effort to study factors influencing the household debt and starting with the most important factors 
mentioned in literature (i.e. GDP, financial worth and interest payment) and adding other potentially less important factors seemed to be more appropriate approach. Some authors recommend this approach in the case that signs of coefficients are correct, see Andrews (2010).

We constructed the sequential model and we performed suitable diagnostic checks in every step. We believe that our theoretical analysis allowed us to cope with the problem of model misspecification. We estimated the models of the household mortgage leverage with the panel data analysis with both the fixed and random effects. To tackle the problem of heteroskedasticity we used robust standard errors, variant $\mathrm{HC} 1$ and Arellano approach (Cottrell, 2003). The multicollinearity was controlled by the Variance Inflation Factors (VIF) method (Adkins, 2012). VIF values lower than the border value 10 (the highest value 2.2 was derived for the old dependency ratio variable) indicated there was no collinearity problem in our set of the explanatory variables. We used the standard significance levels and the test for normality of residuals based on the Jarque Bera procedure. The final models, presented in the Tab. 3 in the next section, passed all the tests.

\section{Tab. 3: Regression models of the household mortgage leverage}

\begin{tabular}{l|c|c|c|c}
\multirow{2}{*}{ const. } & \multicolumn{2}{|c|}{ single taxpayer model } & \multicolumn{2}{c}{ family taxpayer model } \\
\cline { 2 - 5 } & fixed effects & random effects & fixed effects & random effects \\
\hline homeowner tax relief & 0.4824 & 0.3530 & 0.1670 & 0.1276 \\
& $(1.459)$ & $(1.259)$ & $(1.400)$ & $(1.253)$ \\
\hline GDP per capita & 0.04626 & 0.05605 & 0.08523 & 0.08770 \\
& $(0.09976)$ & $(0.1034)$ & $(0.06702)$ & $(0.06768)$ \\
\hline mortgage interest payment & $2.293 \mathrm{e}-05^{\star *}$ & $2.206 \mathrm{e}-05^{\star *}$ & $2.266 \mathrm{e}-05^{\star *}$ & $2.199 \mathrm{e}-05^{\star *}$ \\
& $(3.800 \mathrm{e}-06)$ & $(4.187 \mathrm{e}-06)$ & $(3.330 \mathrm{e}-06)$ & $(3.548 \mathrm{e}-06)$ \\
\hline house prices & -0.003623 & -0.006298 & -0.02391 & -0.02160 \\
& $(0.1509)$ & $(0.1537)$ & $(0.1459)$ & $(0.1463)$ \\
\hline home-rent wedge & $-0.003877^{\star *}$ & $-0.003618^{* *}$ & $-0.003686^{\star *}$ & $-0.003536^{\star *}$ \\
& $(0.001668)$ & $(0.001513)$ & $(0.001678)$ & $(0.001561)$ \\
\hline young dependency ratio & $-0.005812^{* *}$ & $-0.005692^{* *}$ & $-0.005374^{*}$ & $-0.005288^{* *}$ \\
& $(0.002663)$ & $(0.002602)$ & $(0.002694)$ & $(0.002664)$ \\
\hline old dependency ratio & 0.002328 & -0.004443 & 0.009766 & 0.01263 \\
& $(0.06857)$ & $(0.05684)$ & $(0.06408)$ & $(0.05544)$ \\
\hline break-point dummy & -0.09192 & $-0.09518^{*}$ & $-0.09762^{*}$ & $-0.1000^{* *}$ \\
& $(0.05537)$ & $(0.04900)$ & $(0.04768)$ & $(0.04374)$ \\
\hline $\mathrm{n}$ & -0.02961 & -0.03281 & -0.01960 & -0.02110 \\
\hline Adjusted R-squared & $(0.09297)$ & $(0.09480)$ & $(0.08472)$ & $(0.08553)$ \\
\hline & 140 & 140 & 140 & 140 \\
\hline & 0.7205 & $\mathrm{NA}$ & 0.7323 & $\mathrm{NA}$ \\
\hline
\end{tabular}

Source: own

Notes: Standard errors in parentheses. * indicates significance at the $10 \%$ level, ${ }^{* *}$ indicates significance at the $5 \%$ level, based on robust (HAC) standard errors. R-squared is a measure of the proportion of the variance in the household mortgage leverage that is predictable from our set of the independent variables. NA means that this measure is suitable only for linear models but not for random effects models (Adkins, 2012). Wald test results for joint significance of time dummies: chi-square $(9)=505.436$ for the single taxpayer model, 327.4 for the family taxpayer model with both $p$-values near zero. According to these results we decided to include time dummies into the models, nevertheless regression coefficients are suppressed. Hausman test with HO that GLS estimates are consistent: Chi-square $(17)=74.0062$ with $\mathrm{p}$-value $=4.35784 \mathrm{e}-009$ for the single taxpayer model, 35.8286 with $\mathrm{p}$-value $=0.00483423$ for the family taxpayer model. Robustness of models was tested by the $\mathrm{F}$ test for the omission of variables with $\mathrm{H} 0$ : parameters are zero for the variables. Tests delivered $\mathrm{F}$ test statistics with p-values near zero for all models. Results of the diagnostic residual tests are presented only for our fixed effects models. Test for normality of residual: chi-square $(2)=6.84189$ for the single taxpayer model, 5.57706 for the family taxpayer model with both $p$-values $>0.01$. 


\section{Results}

Tab. 3 shows the regression models of the household mortgage leverage. In the second and third columns we assume that mortgages are taken out by the unmarried taxpayers, in the last two columns the married taxpayer with two children is considered as a representative of mortgage borrowers.

It seems that the models for the taxpayers with different marital status and number of children, but with the same income, are similar. Namely coefficients for the GDP, house prices, home-rent wedge and old dependency ratio variables are almost the same in both models. We guess that the analysis results are not sensitive to family status of the taxpayer. In the following text we comment on results for the taxpayers together. In addition we comment only on the fixed effects model results because this model proved more suitable for the estimation of the relationship between the explained and explanatory variables (see the section 2 ).

Regarding our key variable of interest we find no statistically significant impact of the income tax provisions related to owner-occupied housing on the household mortgage leverage. At least, our key variable has a correct sign the tax advantage might provoke households to finance their dwellings by debt. Moreover, family taxpayers exhibit slightly higher propensity for the indebtedness because they are eligible for a higher tax relief.

The preliminary analysis recommended excluding the financial worth per capita (first differences) and the unemployment variables and use the GDP per capita variable as a more suitable measure of the economic level. The GDP variable produced statistically significant effect with a positive sign which corresponds with economic reasoning: a higher mortgage leverage is more probable in wealthier countries.

The sign for the mortgage interest payment variable is consistent with the theory on the relationship between the interest as a price and the amount of a loan in all the models. Nevertheless the effect of the interest is not significant.

Coefficients for the two variables expressing influence of the prices of housing are statistically significant and their interpretation is consistent. The negative coefficient for the development of house prices suggests that the price growth probably diminished the demand on the own housing and thus need to borrow. The negative effect of the home-rent wedge means that the own housing became more expensive in relation to the rental housing and therefore the households might prefer the rental housing. It could lead to the reduced demand on the housing market and consequently to a lower amount of mortgage debt taken up.

The coefficient for the young dependency ratio variable is positive, as expected, but insignificant. Moreover there is, also expected, a negative relationship between the portion of old people and the household debt. This coefficient is significant but only in the family taxpayer model.

The break-point dummy variable for changes in the measuring of the explained variable data was included in all the models. The preliminary analysis of data revealed significant changes in the methodology of the measuring of the household mortgage leverage and the dummy variable seemed to be an appropriate way how to handle this breaks in time series.

\section{Conclusion}

We addressed the issue of the relationship between the income tax relief for homeowners and the household mortgage leverage because a number of economists agree that the deductibility of the mortgage interest payment in combination with non-taxation of the imputed rent probably encourages households to borrow so much that a high debt causes adverse effects both on micro and macro-level.

To our knowledge the first and so far unique statistical cross-country analysis has been undertaken by Wolswijk (2005). We decided to follow the Wolswijk's (2005) work but we used different explanatory variables, especially our variable capturing the income tax relief for homeowners was more elaborate, and data on a later time period. While Wolswijk analysed the effect of the mortgage interest deductibility on the mortgage debt in $15 \mathrm{EU}$ countries over the period 1982-2003 we worked with data for the EU countries (except Greece) during the period 2004-2013. The different factors of concern and another time span might be the reasons why we obtained different results than Wolswijk did. Our regression coefficients for the tax relief variable were positive in all the models which suggests that the income tax relief for homeowners encouraged households to finance their housing with mortgage. This 
outcome can be supported by the higher value of the family taxpayer coefficient in comparison with the value of the single taxpayer coefficient. Increased tax relief is related to the higher level of the household debt. Our result is similar to the Wolswijk's finding that households borrowed more when the mortgage interest was subsidised through the income taxation. However our tax relief variable was not significant in any model estimated using the panel data analysis with fixed effects, which we preferred to the random effects. On the contrary the Wolswijk's estimates were significant.

The other factors could have impact on the household leverage instead. Our analysis revealed that the leverage was influenced significantly by GDP and the price of own housing (measured by the house prices index and the difference between own and rental housing). Our positive effect of GDP is consistent with the Wolswijk's positive effect of wealth, i.e. a higher GDP or disposable income as well as possession of stocks could increase affordability of own housing or lead households to invest more to houses. Our negative effect of the price of own housing is opposite to the Wolswijk's positive effect of house prices. According to his result the higher prices could raise amounts of mortgage necessary to take up or could provide an incentive to acquire a house in order to make a profit in the future. The interest payment and population structure factors could impact the household leverage as predicted but these estimates were not significant in our analysis. On the other hand financial deregulation measures and consumer price inflation had significant effects in the Wolswijk's models. While financial innovations probably made mortgages available for a larger part of the population the consumer price inflation reflected in higher nominal interest rates could reduce the mortgage demand.

Since our model is satisfactory from statistical diagnostic tests point of view we cannot verify the hypothesis that the income tax incentive for the homeownership contributed to the household indebtedness (the coefficients in question were not statistically significant). Our finding thus does not support the opinion of the number of authors who claimed that the tax advantage for the homeownership worked to encourage higher levels of household debt. There were the other factors which influenced households' decision-making on whether to borrow for housing. On the other hand we can agree with those authors who think that the income tax provisions in favour of own housing are not an efficient fiscal instrument to attain the goal of boosting the homeownership. Moreover, our results do not prevent us from endorsing the proposals to cut back or even eliminate the mortgage interest payment deductibility. Benefits of reduction of the debt bias in the housing taxation could be a higher tax revenue, because of a wider tax base or absence of the credit lowering the tax liability, a greater progressivity of the income tax, since the change should increase especially the tax burden of the higher-income households, and lower costs of taxation related to less complicated tax law or administration. However these conclusions were based on the analysis of the data for the selected European countries and given period.

Finally, it is necessary to admit some limitations of our analysis which must be taken into consideration when interpreting the results. When we constructed our homeowner tax relief variable we ignored taxation of capital gains related to a potential house sale and property taxation which can compensate for the imputed rent exemption. Moreover, the capital costs and tax wedges were estimated for taxpayers with certain characteristics. In addition, the taxation information we worked with were not perfect.

Our research is one of outputs of the research project No. GA14-17777S, Private and Public Debt - A Balance Sheet Analysis of Economic Sectors, supported by the Czech Science Foundation. This article was written also under the institutional support of the longterm conceptual development of science and research at Faculty and Accounting, University of Economics, Prague, No. IP 100040.

We thank the anonymous referee for valuable comments.

\section{References}

Adkins, L. C. (2012). Using gretl for principles of econometrics. Retrieved November 13, 2014, from http://www.learneconometrics.com/ gretl/using_gretl_for_POE4.pdf.

Alan, S., \& Leth-Petersen, S. (2006). Tax incentives and household portfolios: a panel data analysis (WP 2006-13). University of 
Copenhagen, Department of Economics, Centre for Applied Microeconometrics. Retrieved August 11, 2014, from http://web.econ.ku.dk/ CAM/Files/workingpapers/2006/2006-13.pdf.

André, C. (2010). A bird's eye view of OECD housingmarkets(OECDEconomics Department Working Paper 746). Paris: OECD Publishing. https://dx.doi.org/10.1787/5kmlh5qvz1s4-en.

Andrews, D. (2010). Real house prices in OECD countries: the role of demand shocks and structural and policy factors (OECD Economics Department Working Paper 831). Paris: OECD Publishing. https://dx.doi. org/10.1787/5km33bqzhbzr-en.

Andrews, D., Caldera Sánchez, A., \& Johansson, A. (2011). Housing markets and structural policies in OECD countries (OECD Economics Department Working Paper 836). Paris: OECD Publishing. https://dx.doi. org/10.1787/5kgk8t2k9vf3-en.

Ansell, B. (2013). The political economy of ownership: housing markets and the welfare state. American Political Science Review, 108(2), 383-402. https://doi.org/10.1017/ s0003055414000045.

Bernardi, L. (2011). Economic crisis and taxation in Europe (Working paper 652). Societá italiana di economia pubblica, Dipartimento di economia, statistica e diritto - Universitá di Pavia. Retrieved August 5, 2014, from https:// mpra.ub.uni-muenchen.de/31007/.

Bokhari, S., Torous, W., \& Wheaton, W. (2013). Why did household mortgage leverage rise from the mid-1980s until the Great recession? Retrieved September 10, 2014, from http://citeseerx.ist.psu.edu/ viewdoc/download?doi=10.1.1.269.5704\&rep= rep1\&type=pdf.

Bourassa, S. C., \& Grigsby, W. G. (2000). Income tax concessions for owner-occupied housing. Housing Policy Debate, 11(3), 521546. Retreived August 11, 2014, from http:// content.knowledgeplex.org/kp2/img/cache/ documents/1268.pdf.

Cecchetti, S. G., Mohanty, M. S., \& Zampolli, F. (2011). The real effects of debt (BIS Working Paper 352). Basel: Bank for International Settlements. Retrieved July 9, 2014, from http://papers.ssrn.com/sol3/papers. cfm?abstract_id=1946170.

Choi, I. (2001). Unit root tests for panel data. Journal of International Money and Finance, 20(2), 249-272. https://doi.org/10.1016/S02615606(00)00048-6.
Cottrell, A. (2003). Gretl manual: gnu regression, econometrics and time-series library. Retrieved November 13, 2014, from http://www.et.bs.ehu.es/soft/gretl.pdf.

Cottrell, A., \& Lucchetti, R. (2016). Gretl manual: gnu regression, econometrics and time-series library. Retrieved August 13, 2016, from http://gretl.sourceforge.net/gretl-help/ gretl-guide.pdf.

Crowe, C., Dell'Ariccia, G., Igan, D., \& Rabanal, P. (2011). How to deal with real estate booms: lessons from country experiences (IMF Working Paper 11/91). International Monetary Fund. Retrieved August 5, 2014, from http:// www.imf.org/external/pubs/ft/wp/2011/wp1191.pdf.

Debelle, G. (2004). Household debt and the macroeconomy. BIS Quarterly Review, March 2004, 51-64. Retrieved August 7, 2014, from http://www.bis.org/publ/qtrpdf/r_qt0403e.pdf.

Dougherty, C. (2007). Econometrics (3rd ed.). New York: Oxford university press.

Dunsky, R. M., \& Follain, J. R. (2000). Tax-induced portfolio reshuffling: the case of the mortgage interest deduction. Real Estate Economics, 28(4), 683-718. https://doi. org/10.1111/1540-6229.00816.

Dynan, K. E., \& Kohn, D. L. (2007). The rise in U.S. household indebtedness: causes and consequences (FEDS Working Paper 200737). Washington, D. C.: Federal Reserve Board, Division of Research \& Statistics and Monetary Affairs. Retrieved August 11, 2014, from http://papers.ssrn.com/sol3/papers.cfm? abstract_id=1019052.

Elliott, G., Rothenberg, T. J., \& Stock, J. H. (1996). Efficient tests for an autoregressive unit root. Econometrica, 64(4), 813-836. https://doi. org/10.2307/2171846.

Ellis, L. (2006). Housing and housing finance: the view from Australia and beyond. Reserve Bank of Australia. Retrieved August 7, 2014, from http://www.reservebank.govt.nz/ research_and_publications/seminars_and_ workshops/14nov06/2895717.pdf.

European Communities. (2011). Tax reforms in EU member states 2011. Tax policy challenges for economic growth and fiscal sustainability (Taxation paper 28). Luxembourg: Publications of the European Union. https://doi. org/10.2765/15419.

European Communities. (2012). Tax reforms in EU member states. Tax policy challenges for economic growth and fiscal sustainability. 2012 Report (Taxation paper 34). Luxembourg: 
Office for Official Publications of the European Communities. https://doi.org/10.2778/30527.

European Communities. (2013). Tax reforms in EU member states 2013. Tax policy challenges for economic growth and fiscal sustainability (Taxation paper 38). Luxembourg: Office for Official Publications of the European Communities. https://doi.org/10.2778/17282.

European Communities. (2014). Tax reforms in EU member states: 2014 Report (Taxation paper 48). Luxembourg: Office for Official Publications of the European Communities. https://doi.org/10.2778/68699.

European Central Bank. (2009). Housing finance in the Euro area. Frankfurt am Main: European Central Bank. Retrieved October 4, 2014, from http://papers.ssrn.com/sol3/papers. cfm?abstract id $=1325202$.

European Central Bank. (2014). Monetary statistics (full report). Frankfurt am Main: European Central Bank. Retrieved March 14, 2015 from http://sdw.ecb.europa.eu/reports. do? node $=1000004040$.

Eurostat. (2013). The distributional impact of imputed rent in EU-SILC 2007-2010. Luxembourg: Publications Office of the European Union. https://doi.org/10.2785/21725.

Garnier, G. et al. (2013). Recent reforms of tax systems in the EU: good and bad news (Taxation papers, working paper 39). Luxembourg: Office for Official Publications of the European Communities. https://doi. org/10.2778/29576.

Girouard, N., Kennedy, M., \& André, C. (2006). Has the rise in debt made households more vulnerable? (OECD Economics Department Working Paper 535). Paris: OECD Publishing. https://dx.doi. org/10.1787/352035704305.

Glaeser, E. L., \& Shapiro, J. M. (2002). The benefits of the home mortgage interest deduction (NBER Working Paper 9284). Cambridge, MA: National Bureau of Economic Research. https://dx.doi.org/10.3386/w9284.

Gujarati, D. (1995). Basic econometrics (3rd ed.). New York: McGraw-Hill.

Hemmelgarn, T., \& Nicodéme, G. (2010). The 2008 financial crisis and taxation policy (CESifo working paper 2932). Munchen: CESifo $\mathrm{GmbH}$. Retrieved August 15, 2014, from http://www.econstor.eu/ bitstream/10419/30738/1/620102888.pdf.

Hemmelgarn, T., Nicodéme, G., \& Zangari, E. (2011). The role of housing tax provisions in the
2008 financial crisis (Taxation papers, working paper 27). Luxembourg: Office for Official Publications of the European Communities. https://dx.doi.org/10.2778/15613.

Hendershott, P. H., Pryce, G., \& White, M. (2002). Household leverage and the Deductibility of Home Mortgage Interest: Evidence from UK House Purchasers (NBER Working Paper 9207). Cambridge, MA: National Bureau of Economic Research. Retrieved August 8, 2014, from http://www.nber.org/papers/w9207.

Hilber, C. A. L., \& Turner, T. M. (2013). The mortgage interest deduction and its impact on homeownership decisions. Retrieved August 7, 2014, from http://eprints.Ise.ac.uk/49843/1/ Hilber_Mortgage_interest_deduction_2013.pdf.

Im, K. S., Pesaran, M. H., \& Shin, Y. (2003). Testing for unit roots in heterogeneous panels. Journal of Econometrics, 115(1), 53-74. https:// doi.org/10.1016/S0304-4076(03)00092-7.

International Monetary Fund. (2009). Debt bias and other distortions: crisis-related issues in tax policy. Retrieved August 7, 2014, from http://www.imf.org/external/np/pp/ eng/2009/061209.pdf.

Izák, V. (2012). Household indebtedness and economic growth (empirical analysis). European Financial and Accounting Journal, 7(3-4), 10-32. Retrieved August 7, 2014, from http://www.vse.cz/efaj/3.

Jacobsen, D. H., \& Naug, B. E. (2004). What influences the growth of household debt? Norges Bank. Economic Bulletin, 75(3), 103-111. Retrieved August 30, 2014, from https://www.norges-bank.no/globalassets/ upload/publikasjoner/economic_bulletin/200403/jacobsen.pdf.

Jappelli, T., \& Pistaferri, L. (2004). Incentives to borrow and the demand for mortgage debt: an analysis of tax reforms (CEPR Discussion Paper 3903). London: Centre for Economic Policy Research. Retrieved August 7, 2014, from http://papers.ssrn.com/sol3/papers. cfm?abstract_id=420241.

Jorda, O., Schularick, M., \& Taylor, A. M. (2014). The great mortgaging: housing finance, crises, and businees cycles (CESifo working paper 4993). Munchen: CESifo $\mathrm{GmbH}$. Retrieved October 17, 2014, from http://www. cesifo-group.de/ifoHome/publications/workingpapers/CESifoWP/CESifoWPdetails?wp_ id $=19126038$.

Jorda, O., Schularick, M., \& Taylor, A. M. (2015). Leveraged bubbles (CESifo working 
paper 5489). Munchen: CESifo $\mathrm{GmbH}$. Retrieved September 1, 2015, from http://www. cesifo-group.de/ifoHome/publications/workingpapers/CESifoWP/CESifoWPdetails?wp_ id=19166710.

Keen, M., Klemm, A., \& Perry, V. (2010). Tax and the crisis. Fiscal Studies, 31(1), 43-79. https://doi.org/10.1111/j.14755890.2010.00107.x.

Leece, D. (2006). Testing a theoretical model of mortgage demand on United Kingdom data. Applied Economics, 38(17), 2037-2051. https://doi.org/10.1080/00036840500426959.

Levin, A., Lin, C., \& Chu, C. J. (2002). Unit root tests in panel data: asymptotic and finitesample properties. Journal of Econometrics, 108(1), 1-24. https://doi.org/10.1016/S03044076(01)00098-7.

Matsaganis, M. (2014). Estimating the distributional effects of mortgage interest tax relief in Europe. Retrieved August 8, 2014, from http://www.researchgate.net/ publication/228388936_Estimating_the_ distributional_effects_of_mortgage_interest_ tax_relief_in_Europe.

McGowan, M. A. (2013). Housing, financial and capital taxation policies to ensure robust growth in Sweden (OECD Economics Department Working Papers 1024). Paris: OECD Publishing. http://dx.doi. org/10.1787/5k4c0vtc1kkk-en.

Munroe, D. J. (2014). Response of home equity debt to mortgage policy: evidence from a kink and a notch. Columbia University. Retrieved August 11, 2014, from http://www. columbia.edu/ djm2166/munroe_hel_052014. pdf.

Organisation for Economic Co-operation and Development. (2009). The financial crisis: reform and exit strategies. Paris: OECD. Retrieved July 15, 2014, from http://www.oecdilibrary.org/content/book/9789264073036-en.

O'Sullivan, A., \& Gibb, K. (2012). Housing taxation and the economic benefits of homeownership. Housing Studies, 27(2), 267279. https://doi.org/10.1080/02673037.2012.6 49470.

Poterba, J. M., \& Sinai, T. M. (2008). Income tax provisions effecting owner-occupied housing: revenue costs and incentive effects (NBER Working Paper 14253). Cambridge, MA: National Bureau of Economic Research. Retrieved August 7, 2014, from http://www. nber.org/papers/w14253.
Rouwendal, J. (2007). Mortgage interest deductibility and homeownership in the Netherlands. Journal of Housing and the Built Environment, 22(4), 369-382. https://doi. org/10.1007/s10901-007-9090-9.

Saarimaa, T. (2009). Studies on owneroccupied housing, taxation and portfolio choice (Doctoral dissertation). Joensuu: University of Joensuu. Retrieved August 11, 2014, from http://epublications.uef.fi/pub/urn_isbn_978-952219-207-3/urn_isbn_978-952-219-207-3.pdf.

Slintáková, B., \& Klazar, S. (2015a). Analysis of income tax relief for housing and its impact on household indebtedness in Europe, 2004 to 2013. In J. Soukup, T. M. L. Pham, D. Phan, \& M. T. Phung (Eds.), Proceedings of the 2nd International Conference on Finance and Economics ICFE 2015 (pp. 256-264). Ho Chi Minh City: Ton Duc Thang University.

Slintáková, B., \& Klazar, S. (2015b). Impact of the income tax relief for housing on household indebtedness in EU, 20042013. Proceedings of the 19th International Academic Conference held in Florence form September 16 to September 19, 2015 (pp. 782797). Prague: International institute of social and economic sciences. http://www.iises.net/ proceedings/19th-international-academicconference-florence/front-page.

Sommervoll, D. E. (2007). Counterintuitive response to tax incentives? Mortgage interest deductions and the demand for debt (Discussion Paper 492). Kongsvinger: Statistics Norway. Retrieved August 11, 2014, from http://brage.bibsys.no/xmlui/bitstream/ handle/11250/180593/1/dp492.pdf.

Sutherland, D., Hoeller, P., Merola, R., \& Ziemann, V. (2012). Debt and macroeconomic stability (OECD Economics Department Working Paper 1003). Paris: OECD Publishing. http://dx.doi.org/10.1787/5k8xb76rhstl-en.

Toussaint, J. (2013). Mortgage-equity release: the potential of housing wealth for future Dutch retirees. Journal of Housing and the Built Environment, 28(2), 205-220. https:// doi.org/1 0.1007/s10901-012-9301-x.

van den Noord, P. (2003). Tax incentives and house price volatility in the Euro area: theory and evidence (Economics department working paper 356). Paris: OECD. http://dx.doi. org/10.1787/410243688730.

Ventry, D. J. (2010). The accidental deduction: a history and critique of the tax subsidy for mortgage interest (Research 


\section{Ekonomie}

Paper 196). Davis, CA: University of California, School of Law. Retrieved August 7, 2014, from http://ssrn.com/abstract=1498784.

Wolswijk, G. (2005). On some fiscal effects on mortgage debt growth in the EU (Working paper 526). Frankfurt am Main: European Central Bank. Retrieved August 11, 2014, from http://papers.ssrn.com/sol3/papers. cfm?abstract_id=800505. doc. Ing. Barbora Slintáková, Ph.D. University of Economics, Prague Faculty of Finance and Accounting Department of Public Finance Czech Republic barbora@vse.cz

doc. Ing. Stanislav Klazar, Ph.D. University of Economics, Prague Faculty of Finance and Accounting Department of Public Finance Czech Republic klazar@vse.cz 


\section{Abstract}

\section{DOES THE TAX RELIEF FOR HOMEOWNERSHIP HAVE EFFECT ON HOUSEHOLD MORTGAGE LEVERAGE?}

\section{Barbora Slintáková, Stanislav Klazar}

This article presents results of the analysis of the relationship between the tax relief for the homeownership and the household mortgage debt. The advantageous treatment of housing is provided especially by a personal income tax if owner-occupiers do not report imputed rents as income but can deduct mortgage interest costs. This preferred tax status is justified by the existence of positive externalities and a desire to enhance housing opportunities available to citizens. However, evidence that the housing policy via the taxation achieves its objectives is still weak. Moreover the tax provisions for the homeownership benefit rather higher-income households. Furthermore there are indications that the housing taxation encourages levered property purchases and thus contributes to the household debt growth. Since the household indebtedness can have adverse effects on households and macroeconomic performance we focused on the issue whether the income tax relief for homeowners that finance their dwellings via a mortgage does affect the household leverage. We constructed the variable capturing especially the mortgage interest payments deductibility. We employed the multiple regression and data for the former 15 EU member countries (except Greece) for the period 2004-2013. We estimated two models for two representative taxpayers who vary in a family status using the panel data analysis with fixed effects. From our results we inferred that the income tax relief for the homeownership might not have influenced the mortgage leverage significantly in the selected European countries in the given period. The mortgage debt was affected rather by the economic level, price of own housing, mortgage interest payments or demographic structure.

Key Words: Household indebtedness, housing taxation, mortgage interest deductibility.

JEL Classification: G21, H24.

DOI: 10.15240/tul/001/2018-1-004 